\title{
Enhancement in seed quality, growth and yield of wheat (Triticum aestivum L.) through polymer seed coating
}

\author{
T.N. TIWARI*, DIPTI KAMAL AND R.K. SINGH \\ Directorate of Seed Research, Kushmaur, MAU (U.P.) INDIA (Email : tntdsr@ gmail.com)
}

\begin{abstract}
Field experiments were conducted for two consecutive years (2009-10 and 2010-11) during Rabi seasons at the research farm of Directorate of Seed Research, Mau to study the effects of polymer seed coating along with insecticide, bio-agent and natural fillers on seed quality parameters, growth and yield of wheat. One year old seeds of two wheat varieties (HUW-234 and HD- 2824) were coated with 5 different treatments viz., polykote @ $3 \mathrm{ml} / \mathrm{kg}$ seed alone $\left(\mathrm{T}_{1}\right)$, polykote @ $3 \mathrm{ml} / \mathrm{kg}+$ Trichoderma viride @ $3 \mathrm{~g} . / \mathrm{kg}$ seed $\left(\mathrm{T}_{2}\right)$, polykote@ $3 \mathrm{ml} /$ $\mathrm{kg}+$ insecticide (carbaryl) @ 3g/kg seed $\left(\mathrm{T}_{3}\right)$, polykote @ $3 \mathrm{ml} / \mathrm{kg}+$ neem oil @ 10 ml $/ \mathrm{kg}$ seed $\left(\mathrm{T}_{4}\right)$ and in combination of polykote @ $3 \mathrm{ml} / \mathrm{kg}$ + insecticide (carbaryl) @ 3g/kg seed + neem oil @ 10ml/kg seed $\left(\mathrm{T}_{5}\right)$, one uncoated set of seed was kept as control $\left(\mathrm{T}_{0}\right)$. The seeds were shade dried after coating and sown in field using Factorial Randomized Black Design in 3 replications with applying recommended doses of NPK (120:60:40). Results obtained revealed that wheat seed coating with polykote @ $3 \mathrm{ml} / \mathrm{kg}$ seed + insecticide $\left(\right.$ carbaryl) @ $3 \mathrm{~g} / \mathrm{kg}$ seed $\left(\mathrm{T}_{3}\right),+$ neem oil @ 10ml/kg seed significantly increased the seed quality parameters, growth, total dry matter production, yield attributes and finally the yield of wheat over uncoated control. Moreover, polymer (polykote@ $3 \mathrm{ml} / \mathrm{kg}$ seed) coating in combination of insecticide carbaryl @ $3 \mathrm{~g} / \mathrm{kg}$ seed or neem oil @ 10ml/kg seed separately also showed at par results compared to the combination of polykote@ 3 ml $/ \mathrm{kg}+$ Trichoderma viride (@3 g./kg seed) which showed non-significant results on above parameters.
\end{abstract}

Key Words : Polymer, Seed coating, Trichoderma viride, Neem oil, Carbaryl

View Point Article : Tiwari, T.N., Kamal, Dipti and Singh, R.K. (2015). Enhancement in seed quality, growth and yield of wheat (Triticum aestivum L.) through polymer seed coating. Internat. J. agric. Sci., 11 (1): 99-103.

Article History : Received : 09.07.2014; Revised : 15.11.2014; Accepted : 01.12.2014

\footnotetext{
* Author for correspondence
} 